\title{
Acerca do uso da eritropoetina recombinante humana em recém-nascidos pré-termo
}

\author{
On the use of recombinant human erythropoietin in preterm neonates
}

\author{
Flávio Adolfo Costa Vaz*
}

\begin{abstract}
$\mathbf{O}$ conhecimento mais aprofundado e mais detalhado da hematopoese, decorrente do advento e do desenvolvimento dos transplantes de órgãos, dos mecanismos imunológicos e de rejeição e dos procedimentos de sustentação, terminou por revelar novas características e propriedades ou mesmo enfatizar e realçar algumas já existentes, dos fatores reguladores do crescimento hematopoético, as citocinas e o hormônio glicoprotéico, a eritropoetina.
\end{abstract}

A eritropoetina teve sua existência prevista no começo do século XX por Carnot e De Flandre. No entanto, somente a partir da década de sessenta, é que ocorreu a intensificação das pesquisas, inclusive em nosso meio (São Paulo e Ribeirão Preto), propiciando o conhecimento da estrutura, do código genético, da síntese orgânica, das características biológicas e bioquímicas, das funções e da produção industrial da forma recombinante humana.

A sua principal função é induzir e manter a diferenciação eritrocitária, vislumbrando-se aí a sua aplicação para a correção da anemia do recém-nascido, prematuro ou de termo, em substituição à transfusão de sangue, que apresenta sérios riscos e efeitos colaterais sempre presentes.

Neste número do Jornal de Pediatria, encontramos um artigo da Dra. Vera Lúcia L. Rocha e cols., desenvolvido na Universidade Federal do Rio Grande do Sul, intitulado " $O$ efeito da eritropoetina humana recombinante no tratamento da anemia da prematuridade", que nos remete a algumas reflexões. Trata-se de artigo muito bem elaborado: através de uma casuística pura, de uma metodologia ade-

* Professor Titular de Pediatria - Faculdade de Medicina da USP quada, eticamente correta, e de uma análise estatística pertinente, os autores demonstram não somente que as propostas veiculadas foram amplamente corroboradas, mas também que em nosso meio se faz pesquisa de nível internacional.

Vale salientar que os articulistas fizeram menção à anemia da prematuridade com as explicações para a sua gênese segundo diferentes pesquisadores. À exceção daquelas relacionadas diretamente à baixa produção de eritropoetina por fatores ainda não perfeitamente explicados, essas teorias dizem respeito não à anemia da prematuridade como entidade clínica que é, e sim ao prematuro anêmico por diversas causas, tais como espoliação sangüínea, hemolíse, hemodiluição, vida média e meia vida eritrocitária (e reticulocitária) diminuídas, rápido crescimento somático, etc. Até o presente momento, preferimos usar a expressão anemia da prematuridade para uma afecção mais bem individualizada e que não se enquadra em nenhuma das categorias de anemia do período neonatal, quais sejam, anemia por produção inadequada, por perda de sangue, por destruição aumentada e a paradoxal ou das grandes altitudes.

Por outro lado, se a incidência da anemia da prematuridade não é de $100 \%$, e seu diagnóstico somente é firmado depois da $4^{\mathrm{a}}$ semana, torna-se difícil o estabelecimento de uma conduta, seja do tipo profilático, seja do tipo terapêutico. A eritropoetina administrada à criança, na presença de nutrientes (proteínas e ferro), em todas as situações apontadas, inclusive na anemia da prematuridade, como vimos no artigo da Dra. Vera e cols., induz e mantém a diferenciação eritrocitária e reduz, por conseguinte, o número de transfusões sangüíneas. 